\title{
Macroeconomic factors, working capital management, and firm performance-A static and dynamic panel analysis
}

Sarfraz Hussain ${ }^{1,2}$, Van Chien Nguyen (10 ${ }^{3 凶}$, Quang Minh Nguyen ${ }^{4}$, Huu Tinh Nguyen ${ }^{3}$ \& Thu Thuy Nguyen ${ }^{5}$

The aim of the study is to explore the interaction effect of macroeconomics indicators, and working capital flows on financial performance in a developing economy. By using the static and dynamic approach of panel analysis, it has been shown that there is a relationship between the components of working capital and the gross profit and cash conversion duration. Second, while interest rates used as an interaction variable with the average payable days have adverse effects, firm performance would decrease if interest rates increase. The average payable duration extends; instead of primarily regressing, the average payable period positively correlates with firm performance. The conversion cycle of cash has a negative relationship, but it reverses its actions after using interest rate interaction. There is a negative relationship with gross profit in the simple regression exchange rate and cash conversion cycle while using the second interaction variable with the cash conversion cycle, has positive effects. In addition, the exchange rate gets higher to increase the cash conversion length, financial performance will be increased. In addition, the exchange rate gets higher to increase the cash conversion length, financial performance will be increased. This study receives new results, the exchange rate increases, companies that can pay early to payable will get higher firm performance while exchange rate and the interest rate have a significant role in changing the firm performance.

\footnotetext{
${ }^{1}$ Azman Hashim International Business School, Universiti Teknologi Malaysia, Kuala Lumpur, Malaysia. ${ }^{2}$ Government Graduate College, Sahiwal, Pakistan. ${ }^{3}$ Thu Dau Mot University, Thu Dau Mot, Vietnam. ${ }^{4}$ University of Finance-Marketing, Ho Chi Minh, Vietnam. ${ }^{5}$ Thuongmai University, Hanoi, Vietnam.

凶email: chienmpp3@gmail.com
} 


\section{Introduction}

he energy sector has contributed significantly to economic growth (Tran et al., 2020). It concludes that the energy sector is a significant industry in each economy that creates jobs, demand for energy, and economic development. To achieve this, the environmental and business considerations of microtechnology, fuel, and power businesses have predominantly developed in the form of financial performance (Nguyen et al., 2020; Wang et al., 2021; Hashemizedeh et al., 2021). This research aims to identify the factors that affect the need for working capital (WC) in a developing economy. In the context of this study, the need for WC is described as enough funds a company needs to adequately fund the ordinary operating expenses needed to run the company. Functioning current assets and current liabilities are dealt with by WC. WC meets a company entrepreneur's short-term financial needs (Luc, 2018; Tan et al., 2019, 2020). The lower cash flows lead to less need for funding and lower capital costs, which, in turn, increase the levels of investor capital (Seth et al., 2020). Efficient WC has become an essential instrument for continuing companies to improve overall profitability and benefit from the industry (Peng and Zhou, 2019). Deficiencies in regular WC patterns have led to efficient quality models that can test robust liquidity (Song et al., 2020). Cash conversion period as firms pay their trade creditors' fees and collect payments from trade debtors that have arisen during the sale of products to consumers (Ukaegbu, 2014). In other words, in response to inventories purchasing and selling, the cash conversion cycle (CCC) is a complex model where it takes time, a business obtained from debtors and paid to payables (Tsagem, 2020). A low stock level of inventory can prevent efforts to sustain a positive WC. Still, the opportunity costs associated with having a positive WC can experience a decrease in gross profit (Mazzarol and Reboud, 2020). Therefore, efficient investment in WC aims to recover excessive investment in current assets when managing a company's ability to find a good balance between liquidity and profitability (Hamza et al., 2015). Yet, there has not been a single investigation into the relationship between components of WC, CCC, and gross profit with the interaction impact of exchange rates and interest rates to preserve the supremacy of our knowledge. Notify the organization to see if the checked association is impacted by the firms' sizes and ages when handling the Interaction between CCC and gross profit (Davis and Bendickson, 2020; Mate and Occhino, 2020).

According to many empirical studies, industry selection is an essential consideration for this research on the company's WC management decision-making. It was the critical goal of exploring how the chosen business deviates from its roots. Different characteristics of the fuel and energy sector, including its internal control system, level of liquidity, firm age, company size, and, in reality, some of the economy's economic determinants, such as interest rates and currency exchange rates. Due to its significance as the country's economy, production infrastructure, and "political tool," the fuel and energy sector is considered unique (Bergeaud and Raimbault, 2020). For instance, a state-owned company monopolized business investment agreements in the Russian power sector (Gazprom Bodislav et al., 2020). Simultaneously, the energy sector of Venezuela was occupied by the official PDVSA, and the Ministry of Petroleum of Iran was in complete charge of the energy sector. They were used as political weapons (Chernov and Sornette, 2020; Rosales, 2020). Finally, the energy market has specific features that impact WC management settlements (Arena et al., 2020; Wattoo et al., 2020; Nguyen, 2020). Previous research on the fuel and energy sector has shown that inaccurate results are produced by the breakdown of critical factors related to growth in the energy sector. Capital and labor, technological development, housing, energy prices, real investment, short-term investment, reproduction, and consumer prices are among these main factors. These variables included the development case that analyzed the relationship between fuel usage and energy consumption and industrial development (Aziz et al., 2020).

For static and dynamic panel regression analyses, a sample of 21 companies working in the fuel and energy field, including the latest results, was utilized in energy production activities for the period 2013-2018. Results show a significant leverage relationship, net cash flow from operations, the volatility of exchange rate and interest rate as moderating impact from macro to microlevel, firm age and size, various components of the CCC on gross profit of firms. This research presents an experimental analysis of the fuel and energy WC investment and the latest data. However, this research finding may be unique for the fuel and energy sector, which has a conglomeration of businesses linked together by cross-shareholders to form a robust system of firms WC arrangements as a prevailing feature of the local economy. The current research contributes to the literature that the moderate role of companies' external environmental factors could initially change the business's internal financial arrangements, taking a sample from a developed economy. Only in the capacity of the model can the findings of our analysis be generally applicable. Lastly, the period adopted in this research (2013-2018) has seen many economic fluctuations, such as economic downturn and policy change, that may vary under normal circumstances for companies or economies. This study adds to previous literature on the relationship between the efficacy of the WCM and the exchange rate and interest rate interaction vector for firms' WC activities. Furthermore, this research is one of the few academic studies to explore this relationship between the exchange rate and interest rate in the fuel and energy industry with CCC and APD of the firms, bridging the gap in related analysis in other industries.

The article goes ahead with attendance: In the section "Literature review", review of the literature. Next, the data and method of investigation are given in the section "Data and methodology". This investigation's results are supported by the section "Results" at the end abstracts and conclusions in the section "Conclusions and limitations".

\section{Literature review}

Earlier research has indicated that the management of WC contributes well to gross profit (Lazaridis and Tryfonidis, 2006; Gill et al., 2010; Adekola et al., 2017; Boisjoly et al., 2020). Earlier literature found that the inverse relationship between these dimensions was commonly observed by WCM and the gross benefit association (Karim et al., 2017; Samiloglu and Akgün, 2016; Chowdhury et al., 2018). Research findings show a negative and essential profitability effect of the debt-equity ratio (Chandra et al., 2016; Öztürk and Karabulut, 2018; Putri and Nasution, 2018). Companies' age and size influence the company's overall profitability (Goel and Sharma, 2015; Moussa, 2018). Liquidity is a significant concern for businesses and can significantly affect their overall profitability (Gull and Arshad, 2013; Wichitsathian, 2019; Umadevi and Boopathiraj, 2020). Possible net cash flows from operations analysis imply that individual businesses have trouble achieving profit results that may adversely impact the financial output (Umadevi and Boopathiraj, 2020; Wang et al., 2020; Nguyen, 2020). Exchange rates directly affect their financial outcome as companies import their inputs or sell their trading inventory on the international market, resulting in a direct competitive impact on domestic and international markets. Falls in demand for foreign trade (Oseifuah, 2016). 


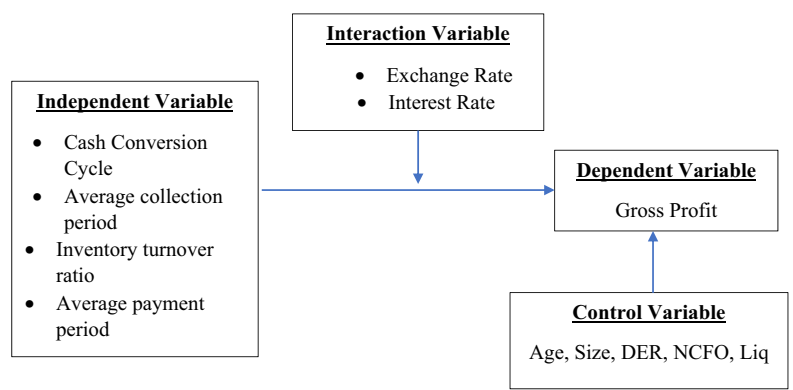

Fig. 1 Conceptual model of the study. This figure explores the graphical flow of the study. The CCC, ACP, ITR, and APP are used as the independent variables while the exchange rate and the interest rate are used to check the macroeconomic factor moderating role on firms financial performance, i.e., gross profit. We also used some control variables Age, Size, DER, NCFO, Liq. Source: authors.

$\mathrm{H}_{1}$ : There is a negative correlation linking $\mathrm{CCC}$ and the fuel and energy sector's gross profit.

The moderating impact of real effective exchange rate (REER) volatility in between CCC and gross profit. Long-term CCC tends to raise the number of inventories and receivables, which extends WC. In this example, to fund account receivables and inventory inventories, outstanding payments/accounts payables, interest-bearing debt, and shareholder equity are used. Therefore, high external sources minimize gross profit precisely because of much interest and fixed funds that will not be reinvested in profitable operations. CCC's yield effect can remain distinct (Goel and Sharma, 2015; Moussa, 2018). Notice that when negotiating with the CCC and the gross profit association to assess the REER, the exchange rate, i.e., the REER, should be considered (Sunday, 2018; Hussain et al., 2020). It is proposed that CCC's shock to gross profit is not due to its structure; REER is supposed to affect it. Some research indicates conflicting conclusions on the relationship between CCC and gross profit could be due to the business's dealing with the exchange rate. In such situations, it is expected that the exchange rate can moderate the CCC and the gross profit association; the resulting hypothesis is then implemented (Dalci et al., 2019).

$\mathrm{H}_{2}$ : The exchange rate has a moderating influence between CCC's relationship and the gross profit of fuel and energy firms.

Moderating impact of interest rate in between CCC and gross profit. The interest rate includes the lending rate provided on the free market by commercial banks. Because of taxes and insolvency costs, interest rate increases are likely to affect its capital structure. In general, companies are more likely to operate on debt while borrowing rates are low. Concerning interest rates, tax advantages are an enticing feature of servicing debt. Business operations will benefit from enhancing financial efficiency, as interest payments are tax-deductible. Generally, businesses borrow more when the cost of funding decreases because it offers companies the opportunity to invest less money on the interest of borrowing funds (Restrepo et al., 2019). It has total power to meet its interest payments if a company's status is stable and profitable. It is also speculated that many companies have low-interest coverage ratios when interest rates are cheap, and they work to make a high profit. Besides, lower interest rates would start a more robust output (Bruyland et al., 2019). This study examines the moderating role of market variables in the relationship between working capital management (WCM) and companies' profitability listed on the TSE from 2008 to 2017. In this analysis, three issues are mediating variables based on current studies, including business size, debt ratio, and government ownership. Using return on assets (ROA) and CCC, respectively, financial performance and WCM are calculated (Zaher and Illescas, 2020).
The importance of integrating macroeconomic variables in the formulation of WCM policies, such as inflation rates. It is expressed in the results that show that inflation has a negative and detrimental effect on WCM and business profitability (Simon et al., 2019).

$\mathrm{H}_{3}$ : The interest rate has a moderating influence between CCC's relationship and the gross profit of fuel and energy firms.

At the base of the above-mentioned theoretical frame and assumptions, the conceptual model can be exhibited:

Conceptual framework. Figure 1 depicts the conceptual framework regarding the study. More specifically, this conceptual model very clearly shows the original paradigm of the research. The CCC and average collection period, inventory turnover ratio, and average payment period are independent variables. The exchange rate and the interest rate used as moderator effects of the macro-factor affect the firm's performance. We can say macro-factor means external environment effect, which is beyond the firms' financial managers' power. Still, they must consider these to build the monetary policy to get firm performance in best of firm's interest. While there are eight different performance indicators of the firm's financial performance, we use only one primary performance indicator: gross profit. Simultaneously, we also use some control variables: firm's age, firm's size, debt-equity ratio, net cash flow from operations, and liquidity ratio of the firms.

\section{Data and methodology}

This section of the study describes analytical techniques for examining patterns, variables, development of research assumptions, and the CCC's interdependence and gross profit components.

Data and sample. The study sample included 21 registered companies employed in the fuel and energy sector. The first fuel and energy sector was carried out questionable results to avoid. Such conditions, such as the effect on gross profit on WC. The key focus of the analysis here is the moderating impact on the gross profit of the exchange rate and interest rate, the net decision on payments and receivables, and the focus on this economic variable's inventory turnover ratio. They appear to be affected and include company results, which can fluctuate across business sectors. All the companies chosen are listed on the Pakistani Karachi stock exchange (KSE). The selected sample describes six years from 2013 to 2018, and the data was obtained from the Department of Statistics of the State Bank.

The hypothesis of the study. Based on the previously discussed aims, the following hypotheses concerning the fuel and energy sector are described. 
$\mathrm{H}_{1}$ : There is a negative correlation linking $\mathrm{CCC}$ and the fuel and energy sector's gross profit.

$\mathrm{H}_{2}$ : The exchange rate has a moderating influence between CCC's relationship and the gross profit of fuel and energy firms.

$\mathrm{H}_{3}$ : The interest rate has a moderating influence between CCC's relationship and the gross profit of fuel and energy firms.

Tools and techniques/Research methodology. The mean, standard deviation, and coefficient of variance are used to determine the effect of the interest rate and exchange rate as moderate with CCC and its components on GP. The correlation coefficient is applied to obtain the relationship between CCC and GP and CCC parts with GP. For the static panel, PCSE is used to address the standard error, which covers autocorrelation (AR) and heterozedastic problems after implementation of the Relationship (AR1) and Correlation (PSAR1) rhotypes (tscorr).

The "small" alternative is used for this reason in the GMM model regression to measure the results of the regression $t$-test instead of $z$ during the analysis of linear and nonlinear regression analyses. To "robust" also helps to handle the heteroscedastic problem and stable AR (HAC). The nodiff-Sargan order is used to prevent the reporting of a particular difference in Sargan statistics. An orthogonal choice is used instead of the first difference to transmit orthogonal variations transform.

Variables. In the investigator's inquiry and what is called during the experiment, an experimental variable counts. The experimental variable answers the explanatory variable. It is calculated because the variations in an explanatory variable are "dependent" on it. The gross profit (GP) is used in this analysis as companies' profitability and is, therefore, an answer variable. The concept of applying this variable is because the study attempted to relate the company's organizational performance or failure to an operational ratio, and it has an intense relationship with other operating variables. Gross profit is calculated as net profits minus the cost of selling products. This research illustrates just how much gross profit a corporation can earn from controlling its current liabilities by investing in existing assets. As gross profit is the performance of any company's trading account, it may be beneficial to begin by focusing on observing each portion of a trading account.

In the sense of financial results, this study's primary aim is to find WC deeply, so it should genuinely concentrate on the trading account because it has roots to improve its economic efficiency. Average receivable days, average payable days, inventory turnover days, and CCC are indicators or regressor variables. ARD is average receivable days, measured as (average receivable accounts/net sales)*365, while the days of inventory turnover are (average inventory/net sales) $\times 365$. APD is $\times 365$ average payable days (average accounts payable/cost of products sold), but as (ARD + ITR-APD), these variables' performance is CCC. A control variable is a constant variable to measure the interaction between two variables. In every experiment, the control variable is not an independent variable, but it can influence the experiment's effects. It refers to the variable generated or dropped to define the relation between a dependent variable and an independent variable. The empirical analysis model, where control variables are debt-equity ratio, liquidity, net cash flow from operations, firm age, and size, are used. Debt equity ratio, gross debt ratio (short-term plus long-term) to total assets. Current assets/current liabilities calculate liquidity. The exchange rate is the REER, while the interest rate is supplied by economic data obtained from the State Bank by the various commercial banks. All information is shown in Table 1.
Empirical model. Introduce research work to explore how variables impacting company gross profit (GP) using the panel data analysis of cross-sectional time-series data ended over the (2013-2018) areas. GP will be used as a response variable with a combination of variables; hence gross operating profit can be interpreted as follows:

Gross Profit $=F(A R D$, ITR, APD, Age, Size, DER, NCFO, Liq, Irate, ExR $)$

Gross Profit $=F($ CCC, Age, Size, DER, NCFO, Liq, Irate, ExR $)$

Simple linear regression, $Y_{i t}=\alpha_{i t}+\beta_{i t} X+\varepsilon_{i t}$

Static panel model: In Panel data analysis, different analysis models can be tested, pooled ordinary least square, random effects, and fixed effects model to examine the association among the variables.

Static model interest rate and exchange rate as an interaction effect: The next step uses the interaction term, which is created by the product of two independent variables: the interest rate and average payable days, and regressed to check its influence on the dependent variable, i.e., gross profit shown in the equation. The study's primary concern is to check the macroeconomic (external environment effect) into the micro-level of the firm's financial decisions.

Static panel model. In this study, we apply both the Static panel model and the Dynamic panel model. The difference in both models will be discussed in Table 2 as follows:

$$
\begin{aligned}
\mathrm{GP}_{i t}= & \beta_{i t}+\beta_{1}\left(\mathrm{ARD}_{i t}\right)+\beta_{2}\left(\mathrm{ITR}_{i t}\right)+\beta_{3}\left(\mathrm{APD}_{i t}\right)+ \\
& \beta_{4}\left(\mathrm{AGE}_{i t}\right)+\beta_{5}\left(\operatorname{Size}_{i t}\right)+\beta_{6}\left(\mathrm{DER}_{i t}\right)+\beta_{7}\left(\mathrm{NCFO}_{i t}\right) \\
& +\beta_{8}\left(\mathrm{Liq}_{i t}\right)+\beta_{9}\left(\text { Irate }_{i t}\right)+\beta_{10}\left(\mathrm{ExR}_{i t}\right)+\varepsilon_{i t} \\
\mathrm{GP}_{i t}= & \beta_{i t}+\beta_{1}\left(\mathrm{CCC}_{i t}\right)+\beta_{2}\left(\mathrm{AGE}_{i t}\right)+\beta_{3}\left(\text { Size }_{i t}\right)+ \\
& \beta_{4}\left(\mathrm{DER}_{i t}\right)+\beta_{5}\left(\mathrm{NCFO}_{i t}\right)+\beta_{6}\left(\mathrm{Liq}_{i t}\right)+\beta_{7}\left(\text { Irate }_{i t}\right) \\
& +\beta_{8}\left(\mathrm{ExR}_{i t}\right)+\varepsilon_{i t}
\end{aligned}
$$

Static Model interest rate as interaction effect

$$
\begin{aligned}
\mathrm{GP}_{i t}= & \beta_{i t}+\beta_{1}\left(\mathrm{ARD}_{i t}\right)+\beta_{2}\left(\mathrm{ITR}_{i t}\right)+\beta_{3}\left(\mathrm{APD}_{i t}\right)+\beta_{4}\left(\mathrm{AGE}_{i t}\right) \\
& +\beta_{5}\left(\text { Size }_{i t}\right)+\beta_{6}\left(\mathrm{DER}_{i t}\right)+\beta_{7}\left(\mathrm{NCFO}_{i t}\right)+\beta_{8}\left(\mathrm{Liq}_{i t}\right) \\
& +\beta_{9}\left(\text { Irate }_{i t}\right)+\beta_{10}\left(\mathrm{ExR}_{i t}\right)+\beta_{11}\left(\text { Irate }^{*} \mathrm{APD}_{i t}\right)+\varepsilon_{i t}
\end{aligned}
$$

$$
\begin{aligned}
\mathrm{GP}_{i t}= & \beta_{i t}+\beta_{1}\left(\mathrm{CCC}_{i t}\right)+\beta_{2}\left(\mathrm{AGE}_{i t}\right)+\beta_{3}\left(\text { Size }_{i t}\right)+\beta_{4}\left(\mathrm{DER}_{i t}\right) \\
& +\beta_{5}\left(\mathrm{NCFO}_{i t}\right)+\beta_{6}\left(\mathrm{Liq}_{i t}\right)+\beta_{7}\left(\text { Irate }_{i t}\right)+\beta_{8}\left(\mathrm{ExR}_{i t}\right) \\
& +\beta_{9}\left(\text { Irate }^{*} \mathrm{CCC}_{i t}\right)+\varepsilon_{i t}
\end{aligned}
$$

Static model exchange rate as an interaction effect

$$
\begin{aligned}
\mathrm{GP}_{i t}= & \beta_{i t}+\beta_{1}\left(\mathrm{ARD}_{i t}\right)+\beta_{2}\left(\mathrm{ITR}_{i t}\right)+\beta_{3}\left(\mathrm{APD}_{i t}\right)+ \\
& \beta_{4}\left(\mathrm{AGE}_{i t}\right)+\beta_{5}\left(\operatorname{Size}_{i t}\right)+\beta_{6}\left(\mathrm{DER}_{i t}\right)+\beta_{7}\left(\mathrm{NCFO}_{i t}\right) \\
& +\beta_{8}\left(\mathrm{Liq}_{i t}\right)+\beta_{9}\left(\text { Irate }_{i t}\right)+\beta_{10}\left(\mathrm{ExR}_{i t}\right)+\beta_{11}\left(\mathrm{ExR}^{*} \mathrm{APD}_{i t}\right)+\varepsilon_{i t}
\end{aligned}
$$

$$
\begin{aligned}
\mathrm{GP}_{i t}= & \beta_{i t}+\beta_{1}\left(\mathrm{CCC}_{i t}\right)+\beta_{2}\left(\mathrm{AGE}_{i t}\right)+\beta_{3}\left(\operatorname{Size}_{i t}\right)+ \\
& \beta_{4}\left(\mathrm{DER}_{i t}\right)+\beta_{5}\left(\mathrm{NCFO}_{i t}\right)+\beta_{6}\left(\mathrm{Liq}_{i t}\right)+\beta_{7}\left(\text { Irate }_{i t}\right) \\
& +\beta_{8}\left(\mathrm{ExR}_{i t}\right)+\beta_{9}\left(\operatorname{ExR}^{*} \mathrm{CCC}_{i t}\right)+\varepsilon_{i t}
\end{aligned}
$$




\section{Table 1 Definition of the variables.}

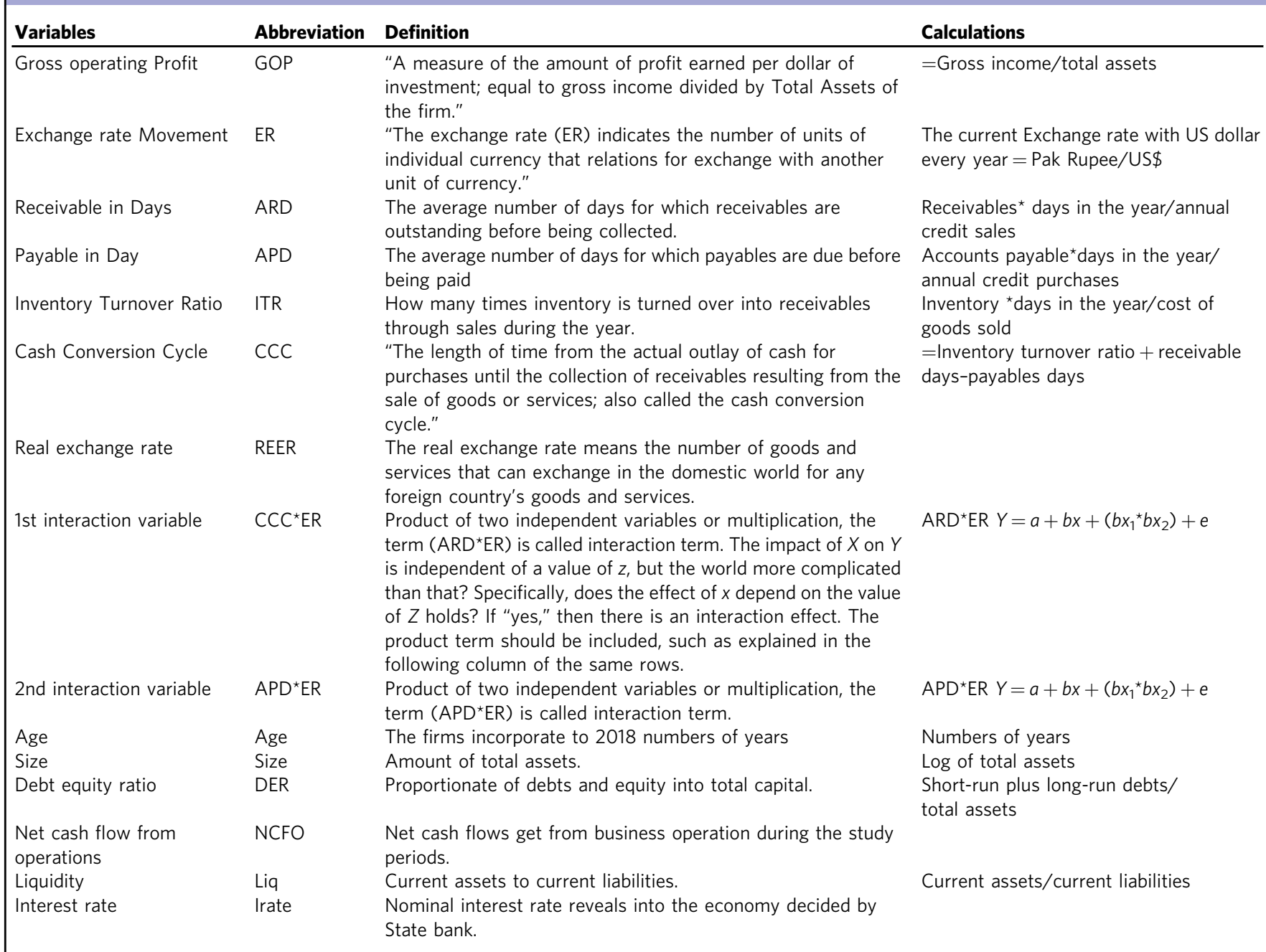

\section{Table 2 Comparison between the different models used in the study for analysis.}

Static Panel Model

Static Model with the interacting effect of intrest rate

Static Model with interacting effect of exchange rate

Dynamic Panel Model

Dynmic Model with interacting effect of intrest rate

Dynmic Model with interacting effect of exchange rate
A panel dataset has both a cross-sectional and a time-series component, where all velocity vector units are observed over the whole period. $Y_{i t}=\alpha_{i t}+\beta\left(x_{i t}\right)+\varepsilon_{i t} x_{i t}, i=1, \ldots, N, t=1, \ldots, T . T$ is usually small. Where interest rate, ccc get multiply and have nonlinear behavior Yit $=\alpha_{i t}+\beta\left(x_{1 i t} \times x_{2 i t}\right)+\varepsilon_{i t}$

Where exchange rate, $c c c$ get multiply and have nonlinear behavior $Y_{i t}=\alpha_{i t}+\beta\left(x_{1 i t} \times x_{2 i t}\right)+\varepsilon_{i t}$

Where leg dependent variable also been used as explanatory variable $Y_{i t}=\delta Y_{i, t}-1+\beta x_{i t}+\mu_{i t}$ Where intrest rate get multiply with another independent variable and GP also use as lag dependent in explanatory variables $Y_{i t}=\delta Y_{i, t-1}+\beta x_{1 i t} \times \beta x_{2 i t}+\mu_{i t}$

Where exchange rate get multiply with another independent variable and GP also use as lag dependent in explanatory variables $Y_{i t}=\delta Y_{i, t-1}+\beta x_{1 i t} \times \beta x_{2 i t}+\mu_{i t}$
Everywhere $i(i=1 \ldots 21)$ is the intercept for every firm, $t$ $(t=2013-2018)$ characterizes the year examined. The $\beta$ are the coefficients for each regressor variable, including $\varepsilon_{i t}$ is the disturbance term. Different approaches will be used to examine the static panel models examined: pooled ordinary least squares, random effects, fixed effects with $n$ firm-specific intercepts. Fixed effects models investigate the relationship between input variables and output variables in different things, considering that the business has its characteristics that influence the association of concerning variables. On the other hand, random-effects models indicate random variation across organizations, unassociated with input variables. Breusch and Pagan's multiplier test tells us that the random effect model is appropriate between OLS and Random Effects. The Hausman test explains the finest model from the second twofold models. In the end, AR and hetero-scedastic problems were resolved using 4-7 regression models, especially with the two-step GMM, which was essential for boosting the expected model. 
Regression from 4 th to 6 th used for panel correction standard error (PCSE).

Dynamic panel model. The dynamic data panel analysis techniques are used to infer the relationships among the variables of the study. To observe our study variables' relationships, we apply a GMM System Estimation applied by Arellano and Bover (1995) and Blundell and Bond (1998). This assessment method will help in the following assessment of the equations: Where (L. $\mathrm{GP}$ ) is the first difference of the gross profit, and the explanatory variables in the model which includes (L.GP), which is the difference lagged dependent variable of Gross Profit. From the empirical model 10th-15th, both L.GP have used the first difference as an explanatory variable because it is conditional in GMM. In this study, we hypothesize a relationship between the firms' gross profit and the interest rate, exchange rate; due to this, it disturbs a company's profitability. In this study, we also hypothesize a relationship between companies' trade creditors and the exchange rate of the PKR. In the present study, we hypothesize an association between companies' trade creditors and the interest rate, exchange rate of the PKR. Many businesses, banking, economics, and finance matters are characterdriven and use panel data arrangements to agree with adjustments. It is essential to allow dynamics in the primary process for the constant estimation of other parameters. The dynamic connections are described by the carriage of a lagged dependent variable with the regressors, i.e. The dynamic model with one lagged dependent variable without exogenous variables, $\mid \gamma<1$, is $Y_{i t}=\gamma Y_{i, t-1}+\alpha_{i}+\mu_{i t} \sim \operatorname{iid}\left(0, \sigma_{\mu}^{2}\right)$ Here, $Y_{i}, t-1$ dependent positively on $\alpha_{i}$ : This is simple to see when inspecting the model for the period $(t-1)$ :

$$
Y_{i t-1}=\gamma Y_{i, t-2}+\alpha_{i}+\mu_{i t-1}
$$

The Arellano-Bond (also Arellano-Bover) method of moments estimator is consistent. The moment conditions use the properties of the instruments

$Y_{i, t-j}, J=2$

To be uncorrelated with the future errors $\mu_{i, t-1}$. we obtain an increasing number of moments conditions for $t=3,4, \ldots, t$.

$T=3: \mathrm{E}\left[\left(\mu_{i, 3}-\mu_{i, 2}\right) y_{i, 1}\right]=0$

$T=4 \mathrm{E}\left[\left(\mu_{i}, 4-\mu_{i, 3}\right) y_{i, 2}\right]=0, \mathrm{E}\left[\left(\mu_{i}, 4-\mu_{i, 3}\right) y_{i, 1}\right]=0$

$T=5 \mathrm{E}\left[\left(\mu_{i, 5}-\mu_{i, 4}\right) y_{i, 3}\right]=0, \ldots, \mathrm{E}\left[\left(\mu_{i, 5}-\mu_{i, 4}\right) y_{i, 1}\right]=0$

We define $(T-2) \times 1$ vector

$\Delta \mu_{i}=\left[\left(\mu_{i, 3}-\mu_{i, 2}\right), \ldots \ldots,\left(\mu_{i, T}-\mu_{i, T-1}\right)\right]$

And a $(T-2) \times(T-2)$ matrix of instruments

$$
\begin{array}{ccccc} 
& Y_{i, 1} & Y_{i, 1} & \ldots \ldots & Y_{i, 1} \\
\dot{z}_{i}=0 & Y_{i, 2} & \ldots \ldots & Y_{i, 2} \\
0 & 0 & \ldots \ldots & \ldots \ldots \\
0 & \ldots \ldots & 0 & Y_{i, T-2}
\end{array}
$$

Ignoring exogenous variable, for $\Delta Y_{i t}=\gamma \Delta Y_{i, t-1}+\Delta \mu_{i t}$

$$
\begin{gathered}
Y_{i t}=\delta Y_{i, t-1}+\beta x_{i t}+\mu_{i t} \\
\mathrm{GP}_{i t}=\beta_{i t}+\beta_{1}\left(\mathrm{ARD}_{i t}\right)+\beta_{2}\left(\mathrm{ITR}_{i t}\right)+\beta_{3}\left(\mathrm{APD}_{i t}\right)+ \\
\beta_{4}\left(\mathrm{AGE}_{i t}\right)+\beta_{5}\left(\operatorname{Size}_{i t}\right)+\beta_{6}\left(\mathrm{DER}_{i t}\right)+\beta_{7}\left(\mathrm{NCFO}_{i t}\right) \\
+\beta_{8}\left(\mathrm{Liq}_{i t}\right)+\beta_{9}\left(\text { Irate }_{i t}\right)+\beta_{10}\left(\mathrm{ExR}_{i t}\right)+\mu_{i t} \\
\mathrm{GP}_{i t}=\beta_{i t}+\beta_{1}\left(\mathrm{CCC}_{i t}\right)+\beta_{2}\left(\mathrm{AGE}_{i t}\right)+\beta_{3}\left(\mathrm{Size}_{i t}\right) \\
+\beta_{4}\left(\mathrm{DER}_{i t}\right)+\beta_{5}\left(\mathrm{NCFO}_{i t}\right)+\beta_{6}\left(\mathrm{Liq}_{i t}\right) \\
+\beta_{7}\left(\text { Irate }_{i t}\right)+\beta_{8}\left(\mathrm{ExR}_{i t}\right)+\mu_{i t}
\end{gathered}
$$

Dynamic model interest rate as interaction effect

$$
\begin{aligned}
\mathrm{GP}_{i t}= & \beta_{i t}+\beta_{1}\left(\mathrm{ARD}_{i t}\right)+\beta_{2}\left(\mathrm{ITR}_{i t}\right)+\beta_{3}\left(\mathrm{APD}_{i t}\right)+ \\
& \beta_{4}\left(\mathrm{AGE}_{i t}\right)+\beta_{5}\left(\mathrm{Size}_{i t}\right)+\beta_{6}\left(\mathrm{DER}_{i t}\right)+\beta_{7}\left(\mathrm{NCFO}_{i t}\right)+ \\
& \beta_{8}\left(\mathrm{Liq}_{i t}\right)+\beta_{9}\left(\text { Irate }_{i t}\right)+\beta_{10}\left(\mathrm{ExR}_{i t}\right)+\beta_{11}\left(\text { Irate }^{*} \mathrm{APD}_{i t}\right)+\mu_{i t}
\end{aligned}
$$

$$
\begin{aligned}
\mathrm{GP}_{i t}= & \beta_{i t}+\beta_{1}\left(\mathrm{CCC}_{i t}\right)+\beta_{2}\left(\mathrm{AGE}_{i t}\right)+\beta_{3}\left(\mathrm{Size}_{i t}\right)+ \\
& \beta_{4}\left(\mathrm{DER}_{i t}\right)+\beta_{5}\left(\mathrm{NCFO}_{i t}\right)+\beta_{6}\left(\mathrm{Liq}_{i t}\right)+\beta_{7}\left(\text { Irate }_{i t}\right)+ \\
& \beta_{8}\left(\mathrm{ExR}_{i t}\right)+\beta_{9}\left(\text { Irate }^{*} \mathrm{CCC}_{i t}\right)+\mu_{i t}
\end{aligned}
$$

Dynamic model exchange rate as an interaction effect

$$
\begin{aligned}
\mathrm{GP}_{i t}= & \beta_{i t}+\beta_{1}\left(\mathrm{ARD}_{i t}\right)+\beta_{2}\left(\mathrm{ITR}_{i t}\right)+\beta_{3}\left(\mathrm{APD}_{i t}\right)+ \\
& \beta_{4}\left(\mathrm{AGE}_{i t}\right)+\beta_{5}\left(\operatorname{Size}_{i t}\right)+\beta_{6}\left(\mathrm{DER}_{i t}\right)+\beta_{7}\left(\mathrm{NCFO}_{i t}\right) \\
& +\beta_{8}\left(\mathrm{Liq}_{i t}\right)+\beta_{9}\left(\text { Irate }_{i t}\right)+\beta_{10}\left(\operatorname{ExR}_{i t}\right)+\beta_{11}\left(\mathrm{ExR}^{*} \mathrm{APD}_{i t}\right)+\mu_{i t}
\end{aligned}
$$

$$
\begin{aligned}
\mathrm{GP}_{i t}= & \beta_{i t}+\beta_{1}\left(\mathrm{CCC}_{i t}\right)+\beta_{2}\left(\mathrm{AGE}_{i t}\right)+\beta_{3}\left(\operatorname{Size}_{i t}\right)+ \\
& \beta_{4}\left(\mathrm{DER}_{i t}\right)+\beta_{5}\left(\mathrm{NCFO}_{i t}\right)+\beta_{6}\left(\mathrm{Liq}_{i t}\right)+\beta_{7}\left(\text { Irate }_{i t}\right) \\
& +\beta_{8}\left(\mathrm{ExR}_{i t}\right)+\beta_{9}\left(\mathrm{ExR}^{*} \mathrm{CCC}_{i t}\right)+\mu_{i t}
\end{aligned}
$$

Wherever $\delta$ is a scalar, $x_{i t}$ is $1^{*} K$, and $\beta$ is $K^{*} 1$. The $\mu_{i t}$ go when a one-way disturbance component model $\mu_{i t}=\lambda_{\mathrm{i}}+\varepsilon_{i t}$ the error term $\mu_{i t}$ is de-integrated into $\lambda_{i}$ and $\varepsilon_{i t}$ where $\lambda_{i}$ is the individual specific effect to cover the individual heterogeneity, and $\varepsilon_{i t}$ is the error term. The empirical model is considered to promote investment variables. Because equity can range from investment to firm equity to debt in both directions and vice versa, these restrictions can be synchronized through the error term. Timeoriented firm individualities (unobserved specific effects, $\lambda_{i}$ ), such as demographics and geography, can remain integrated thru explanatory variables. The presence of the lagged measured variable leads to AR. There are at least two reasons for a short period measurement $(T=6)$ then a firm's measurement $(N=21)$ in the panel data set: the possibility of simultaneous error control makes it possible for some predictor variables might be endogenous (associated). Controlling the firm's exact impact, which is due to the regression calculation's dynamic assembly, the firm's specific dummies cannot be used.

Blandell and Bond (1998) System GMM estimator where Level and differential equations have been merged. The rear differential of the regressors is used as an extra instrument for level equations. Here are two types of GMM estimators, one step and two-step estimator. Academically, a two-step estimation is much extra effective than a one-step estimation since it practices the maximum weight matrix. A minor cross-section measurement might (i) cause influenced standard errors, (ii) influenced estimation parameters (Windmeijer, 2005), and (iii) a weak extraordinary identification test (Bowsher, 2002). Rodman () explained that the source of these difficulties is device expansion. An answer that cuts the measurement of the adjustable instrumental combination. Blundell and Bond (1998) and Alonso-Borrego and Arellano (1999) show that if the dependent and explanatory variables determined and running continuously over time or almost behaving a random walk, the variance of these components, in differences is performing as a weak instrument for Regression (Nyblom, 1989). Due to the autoregressive approximation of the parameter union or the variability of the separate impact rises, it is increasing when idiosyncratic error varies. Therefore, to reduce the potential error and barriers related to difference estimators, Blandel and Bond 
Table 3 Descriptive statistics.

\begin{tabular}{|c|c|c|c|c|c|c|c|}
\hline & Mean & Median & Maximum & Minimum & Std. dev. & Skewness & Kurtosis \\
\hline GP & 13.72 & 14.58 & 18.99 & 0.00 & 3.86 & -1.86 & 7.10 \\
\hline ARD & 0.00 & 0.00 & 0.03 & 0.00 & 0.01 & 3.33 & 13.12 \\
\hline ITR & 19.36 & 7.38 & 350.90 & 0.00 & 49.78 & 5.38 & 34.14 \\
\hline $\mathrm{CCC}$ & -66.87 & -14.92 & 0.00 & -498.53 & 109.68 & -2.22 & 7.53 \\
\hline AGE & 3.26 & 3.14 & 4.71 & 1.79 & 0.64 & 0.20 & 2.89 \\
\hline SIZE & 16.34 & 16.97 & 20.32 & 0.00 & 3.29 & -2.21 & 10.82 \\
\hline LIQ & 2.09 & 1.15 & 23.19 & 0.00 & 3.55 & 4.43 & 23.59 \\
\hline IRATE & 0.08 & 0.08 & 0.10 & 0.07 & 0.01 & 0.11 & 1.42 \\
\hline EXR & 4.66 & 4.66 & 4.71 & 4.59 & 0.04 & -0.37 & 1.80 \\
\hline
\end{tabular}

(1998) projected a GMM method by merging differences and regressions crosswise levels.

In calculating the Regression of differences, the means on behalf of Regression in levels are lagged differences (transformed). The reliability of GMM estimation is contingent on double descriptive diagnostics tests. Sargent tests of excessive instrument restrictions are valid, fail to throw away the hypothesis will mean instruments used in the model are correct, and the research model is properly well-defined. Serial correlation tests for the error term (Arellano and Bond, 1991; Dao et al., 2020). We must reject H0, which implies no first-order AR (AR1) and that the second-order serial correlation does not appear (AR2). Windmeijer (2005) derives a close derivation of this limited sample bias and applies it to the two-step GMM estimation variable variance-covariance matrix (VCE) defining VCE (Robust). Reliable estimates of what has been corrected are robust to heteroscedasticity. The Sargan test output does not indicate that when the errors are heteroskedastic, the estat sargan is not presented the description of the VCE (robust) afterward. A healthy form of the Arellano-Bond test for AR has been developed after defining VCE (Robust).

\section{Results}

Descriptive statistics. Table 3 exhibits the numbers of the variables employed in the investigation. The mean value of GP is 13.72 of the fuel and energy sector firms produce profit constructed on stockholders' investments. The average figure of the debt-equity ratio is 3.59 , the mean value of irate is $7.95 \%$, and the firm's liquidity is 2.09 , respectively. CCC's mean value is around -66.87 , meaning that cash conversion has a negative impact, and it supports the literature on the topic. APD has a mean value of 66.88 , proving that the fuel and energy sector firms attempt to balance current assets to current Liabilities. It indicates that the fuel and energy sector firms also own a low volume of existing assets and have less preference to hold receivable (account receivable/notes receivable), inventory stock, and other few current assets. The next consideration is extra suitable in this situation. Examining the mean value of liquidity is 2.08 , which means a relationship between current assets is very high, showing that half of the assets are equal to short-term debts. Firm Size means the value is 16.34 and Age means is 3.26, net cash flow from the operation has 13.02 mean value.

Correlation matrix. Correlations among all variables exist in Table 4 . The correlation between the debt-equity ratio has a positive effect on GP. There is a negative and significant association with CCC, while APD has a significant association. CCC has a significant negative association with dependent variables, while ARD APD positively affects GP. The control variables, like liquidity, the exchange rate (REER), and interest rate, positively correlate with firm GP. In contrast, all others, including age, size, net cash flow from the operation, have a positive association with gross profit.

Empirical results. Table 5 displays the regression analysis's primary outcomes using static panel and dynamic panel analyses where the firm's gross profit is used as a dependent variable. In contrast, the CCC and WCM components are used as independent variables. Debts equity ratio, firm age, size, NCFO, liquidity used as control variables, exchange rate and irate, are used as moderator (Interaction) variables of the empirical research model. Multicollinearity monitors panel data with VIF, where the mean VIF value $>10$ means that the panel is multi-colinear (Majeed and Ozturk, 2020). The first column reports the names of various independent variables, the second column results for pooled ordinary least squares (OLS), the third column reports the results of random effects (RE), and the fourth column fixed effects (FE) regressions results. At the second point, we use techniques to robust the standard error with the methods of AR parameter is large (54.97), which was not the case without this (24.05). The standard errors are extensive than for the model exclusive of serial correlation 36.05 , which is possible if there is a serial correlation. 5th Column is about Beck and Katz (2011) makes a case in contradiction of estimating panel exact AR parameters, as opposed to one AR parameter for all panels. 5th Column used PCSE with AR; the standard errors are similar to PCSE. However, they are from the asymptotic covariance evaluations of OLS deprived of permitting for coexistent correlation. Outcomes from the two-step system GMM regression are included in the last column.

The influence of WC components related decisions with interest rate and exchange rate on gross profit. The OLS model explains ARD, ITR, APD, age, size, debt-equity ratios, NCFO, liquidity, interest rates, and exchange rate explain the disparity in GP. Debt-equity ratios, Age, Size, interest rate, and exchange rate are negative, while ARD, ITR, APD, NCFO, and Liquidity have positive effects on GP in the case of a fixed-effect model best choice. However, to overcome heteroskedasticity and serial correlation with the error term, we used various PCSE techniques to validate the panel's robust standard error correction. We discovered that all variables' coefficients are identical to those in the fixed effects model, except firm size and firm liquidity behaviors being negative. Size gets positive instead of fixed effects model. Every WC components regression Husman test has been pointed out that the fixed effects are suitable to consider in the model (Veenstra and Vanzella-Yang, 2020), indicating that there is a difference between firms managing associations among variables. 


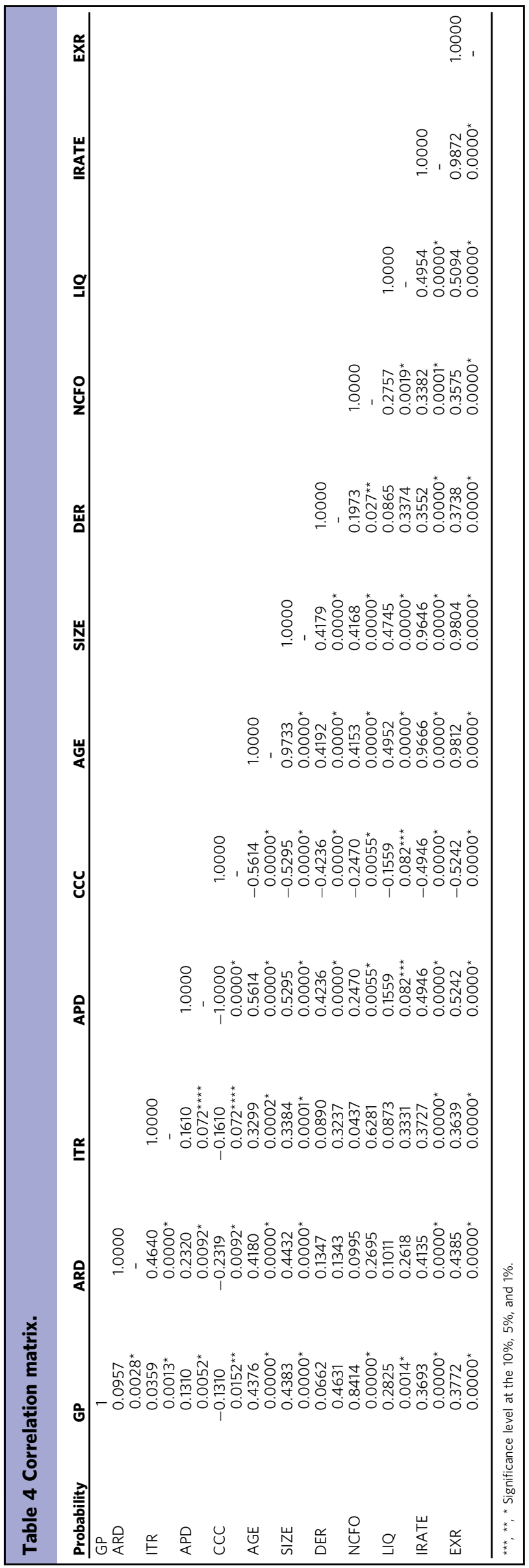

The second aimed a detailed study to estimate the model of fixed effects evaluated for fixed effects, ARs, and heterogeneity for some time. These matters are further explained. The corrected model using PCSE proves the importance of variables in terms of statistics that affect GP (Nuță and Nuță, 2020). ITR, APD, size, $\mathrm{DER}, \mathrm{NCFO}$, and liquidity ratio have slightly changed in betas value, but $A R D$, age, interest rate, exchange rate betas values get colossal change. It is presumed that different lending companies will be less gainful. Gross profit often rises by businesses regularly restoring WC components to their average values, which confirms this experimental model's findings that the fuel and power companies are efficient in using their WC and focusing on them. The straight impact of size on GP shows that businesses are additional gainful when seen with large size, DER reverse influence, perhaps as they remain more careful in allotting their funds. Likewise, the exchange rate increase gives the fuel and energy sector less gross profit, similar to the interest rate. Though, it is identical that businesses uncover their APD during high exchange rate times. The modified, fixed effects that are PCSE calculation yields an adverse factor for size and a constructive for liquidity and investment (Nuță and Nuță, 2020). Accordingly, the fuel and energy firms perform very well when they own a small CCC. Its presumption is established by the liquidity betas, confirming that current assets give chances to earn extra income. Subsequently the PCSE model, the debt-equity keeps its adverse impact on the gross profit. While size, DER, NCFO, Liq, Irate, and exchange rate remained statistically significant.

At the end, when WC components are less favorable, the fuel and energy industry earn more gross profit than CCC components. From the explanatory variables, i.e., CCC, it is confirmed that gross profit is inversely affected whereas positively associated with NCFO and Liq. It sees explanatory variables in the fixed effect model are significant. The logical outcomes were suspected if the maximum of the registered firms examined be obliged a tiny amount of debt, occasionally taking solitary short-term loans. The revised fixed effects using PCSE Regression relating to CCC components manage the gross profit by age, size, DER, NCFO, liquidity, Irate, and exchange rate. CCC is leading an adverse result on the gross profit. We can say that businesses are extra gainful if they put less investment in WC components. They can keep enough in backup to handle the crucial situation of operational activities.

Meanwhile, as Irate or exchange rates are increased, the gross profit will decrease automatically. The GMM model, including the lag value of GP as a regressor, corrected the fixed effects equation. It returned a significant positive coefficient for size and a negative for ARD, ITR. While including the lag value of GP as a regressor, it rotates the coefficient of the following variable, i.e., ARD, ITR positive to negative. In contrast, the size becomes a negative coefficient to a positive sign. It means the GMM model handles the problem of heteroscedasticity and serial correlation problems appropriately. When the model's overall significance is estimating, one needs to check that all regressions are appropriate. A GMM two-step process that adjusts the AR, heteroskedasticity, is most apt to understand the immense benefit output (Beck and Katz, 2011). The estimated association linking these variables simultaneously, including control variables, is shown in Tables 4 and 5. The coefficient of ARD was positive (6.97). It meant that when ARD increased by 1-day, gross profit increased by $6.97 \%$. The regression beta of the ITR was 0.006 , indicating that an increase of 1 in the ITR is a $0.06 \%$ increase in gross profit and vice versa. It shows that higher inventory levels will support overall profit growth.

The APD coefficient was 0006, showing a rise in APD of 1 to an increase of 0,06 percent in gross profit. In a different approach, approximately, when the APD increases by 1 , the gross profit increases by $0.06 \%$. The 2 nd regression equation's coefficient of 


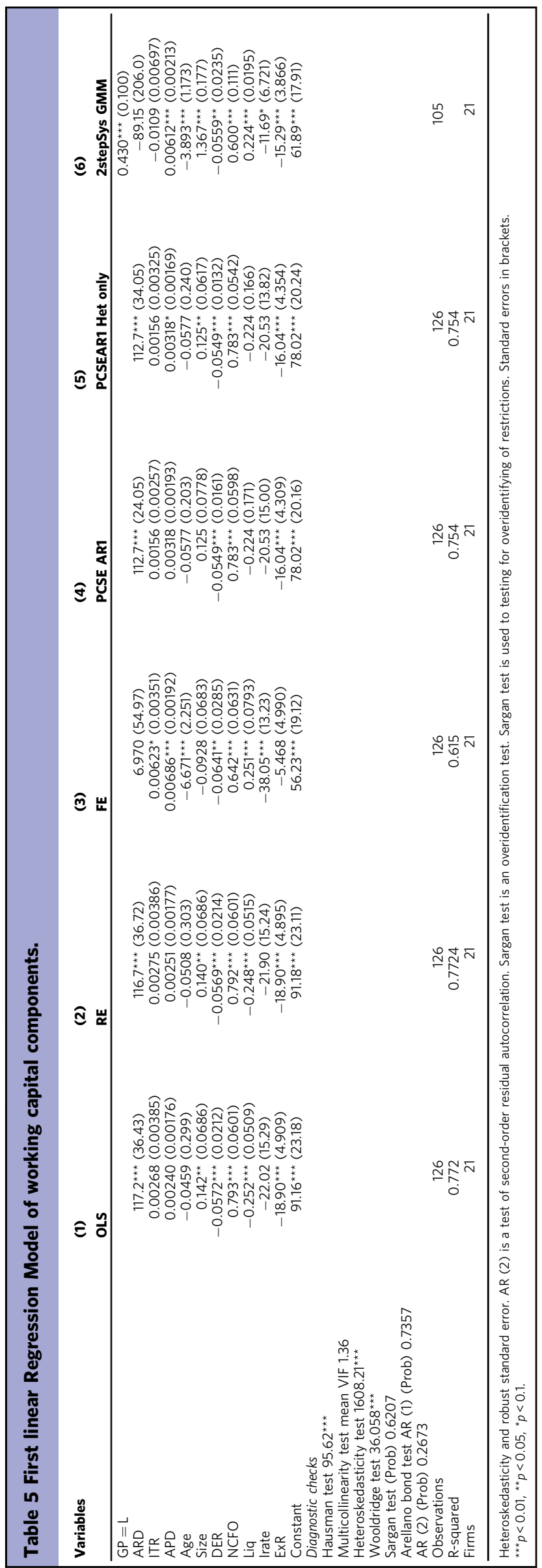

CCC was -0.0061 and significant, which indicates that an expansion in CCC by 1 unit is associated with a decrease in GP by $0.006 \%$ and vice versa. The Hausman test is significant. In all the cases, the FE model is consistent; the VIF ranged from 1.30 to 1.36 , mean no multicollinearity problem exists in linear Regression, but its value is more than 10 in the case of nonlinear equations. It indicated that a specific variable had some associations with other predictor variables. The heteroskedasticity test and Wooldridge test show that both problems exist to adjust with PCSE and system GMM. It means that multicollinearity and serial association problems may be modified correctly after these approaches are used. If the Sargan test's $p$-value and that the AR1 and AR2 values are not significant, it means aligning all of the issues.

The influence of CCC-related decisions with interest and exchange rate on gross profit. Concerning gross profit, the models referring to age, size, debt-equity ratios, NCFO, liquidity ratio, interest rate, and exchange rate give a statistically meaningful result in all the models. Going on the opposite, the CCC has a negative relation with GP. The NCFO and Liquidity ratios were also observed as statistically positive for the variance of GP. The exchange rate and interest rate were also observed statistically negative with the variance of GP, nevertheless all empirical regressions model especially in GMM. Although all relevant regressions were applied (OLS, RE, FE, PCSE, GMM), the goodness of fit indicates that all variables were analyzed to determine and points out that these observed variations in GP happen due to all selected variables. Ultimately, the most suitable approach for this model is PCSE and GMM adjusted and satisfy all linear and nonlinear regression appropriations. Based on the results shown in Table 6, lending firms are less efficient. It is observed through some associations that gross profit will be influenced by the high degree of debt-equity ratio, and further, it is found the corporations that buy current assets by their funds.

Nevertheless, it can also be thought that corporations invite investors with investment opportunities. Therefore corporations that acquire additional current assets promote more considerable investment in CCC activities of the business. The direct effect of the NCFO on GP suggests that when the NCFO increases, it will enhance the GP in the fuel and energy sector firms. The CCC, firm age, DER, NCFO, Liquidity, Interest rate all these variables were found statistically significant in the FE model.

Additionally, the corrected FE through the PCSE model proceeds size, DER, exchange rate (REER), and significant interest rate values. The exchange rate and interest rate have an adverse effect, and liquidity and NCFO have a progressive GP impact. In further terms, the firms yield higher on stockholders' funds while liquid assets are better. It is shown in the GMM model. Another assumption would be that under ARD and ITR, the firm's gross profit gets shrinkage, big size firms get more GP. Thus, they are trying to attract more investment opportunities and collect more competitive opportunities in the market.

Interaction effect. The interaction effect's significance is these nonlinear empirical models, where it is not like the indifferent effect; it may have a distinct symbol. The usual software does not calculate the significance of this statistic. The exact way to evaluate its measurement and standard errors is the nonlinear model's interaction effect (Ai and Norton, 2003). We enter the interaction term in the experimental model interest rate and APD (Irate*APD), positive and interest rate. In another equation, CCC (Irate*CCC), which coefficient is negative, can measure the different slopes of the coefficient. It has too much change in the coefficient value and their signs of both variable interest rate and APD. It means interest rate has an interaction effect between firms' APD and their GP (Jadiyappa et al., 2016). 

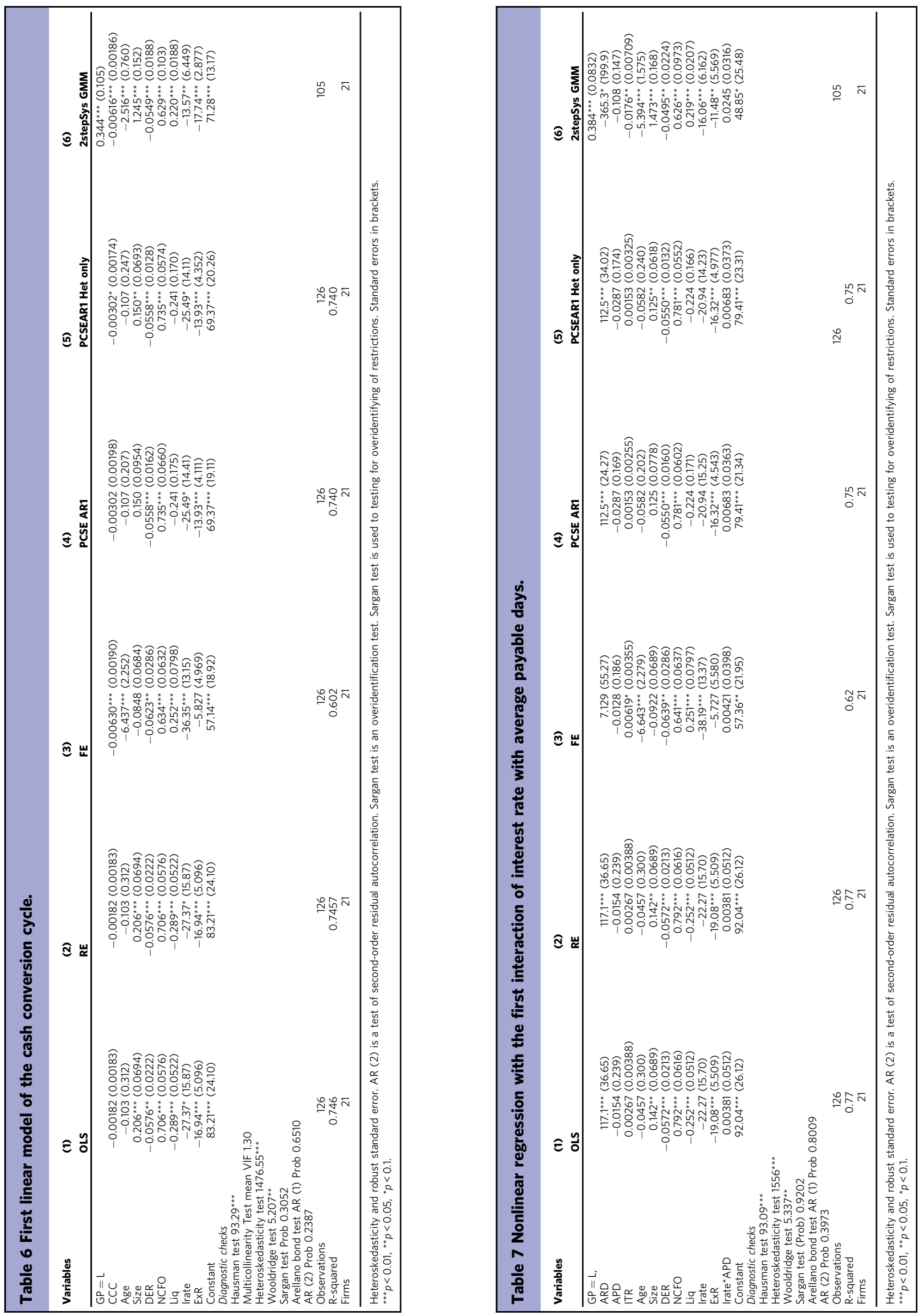
Table 7 clearly explains the Interaction with both variables. In our output table, Diagnostic checks present the evaluation first model selection using the Hausman test. We infer the FE is appropriate in GP as the dependent variable with different CCC components. The Hausman test helps us differentiate between RE and FE, so the probability value Hausman test is $<5 \%$, so our choice is FE is appropriate.

Multicollinearity Test means VIF is little more than the simple model without interaction effect. It was only $1.30-1.36$, but after the model's interaction variable, it gets higher mean there is multicollinearity in the model. Heteroskedasticity test also significant mean model caught by Heteroskedasticity problem. Therefore, we use both PCSE for the static and two-step system GMM for the dynamic panel to cover this problem. Wooldridge test helps us identify an AR problem, but in our case, all models have this problem; that's why we use PCSE AR1, and in GMM, we use the AR1 AR2 technique to adjust this problem correctly. Sargan test helps us to find out that model and overidentification conditions are correctly specified. If the Sargan test's $p$-value is insignificant, then $\mathrm{H}_{0}$ that overidentification conditions are correctly specified is accepted whether the instruments appear exogenous. In the end, all GMM models of the study lag variables are significant to mean it fulfills the condition of the dynamic model.

Here in Table 8, Irate* CCC is used as a regressor to check the interaction effect, which is approved to have an interaction effect because the value of the coefficient has changed.

Table 9, we enter the interaction term in the experimental model exchange rate and CCC (ExR*APD). Coefficients are positive and (ExR*CCC) which coefficients are negative and can measure the coefficient's different slope. It has too much change in the coefficient value and their signs of both variable interest rate and $\mathrm{APD}$. It means interest rate has an interaction effect between firms' APD and their GP (Jadiyappa et al., 2016).

Here in Table 10, ExR*CCC is used as a regressor to check the interaction effect, which is approved to have an interaction effect because the value of the coefficient has changed. This interaction effect is considered as financial development and evaluated by the researcher (Ahmed et al., 2020; Asif et al., 2020).

Based on previous results, all three research hypotheses have been accepted.

\section{Conclusions and limitations}

The objective of the study is to examine the interaction effect of macroeconomics indicators, and WC flows on financial performance in a developing economy. By using the static and dynamic approach of panel analysis, and firm-level dataset from 2013 to 2018, empirical results show that the firm either does not efficiently control current assets or has sufficient funds from companies to tackle advantageous schemes. Size has a significant effect on gross profit. More specifically, large sizes are considered to have a considerable impact on the firm performance. Similarly, the exchange rate has an adverse relation with firm performance. Although this indicates that huge profits are connected to low exchange rates, it is further rationale to investigate that the fuel and energy industry accounts for most of its foreign exchange inputs and local currency turnover in cases of excessive exchange rates. When PCSE research methods were used, it would also show the adverse correlation between the interest rate and its firm performance. Further, the relation between CCC and financial performance is significantly affected by NCFO. While businesses run debt when they are in financial difficulty when the interest rate is high, it has an inverse impact on GP; they face significant business risks or do not pay outstanding due to cash shortages.

Moreover, several variables can be classified to help clarify the fluctuation in financial performance. Interest rates are more

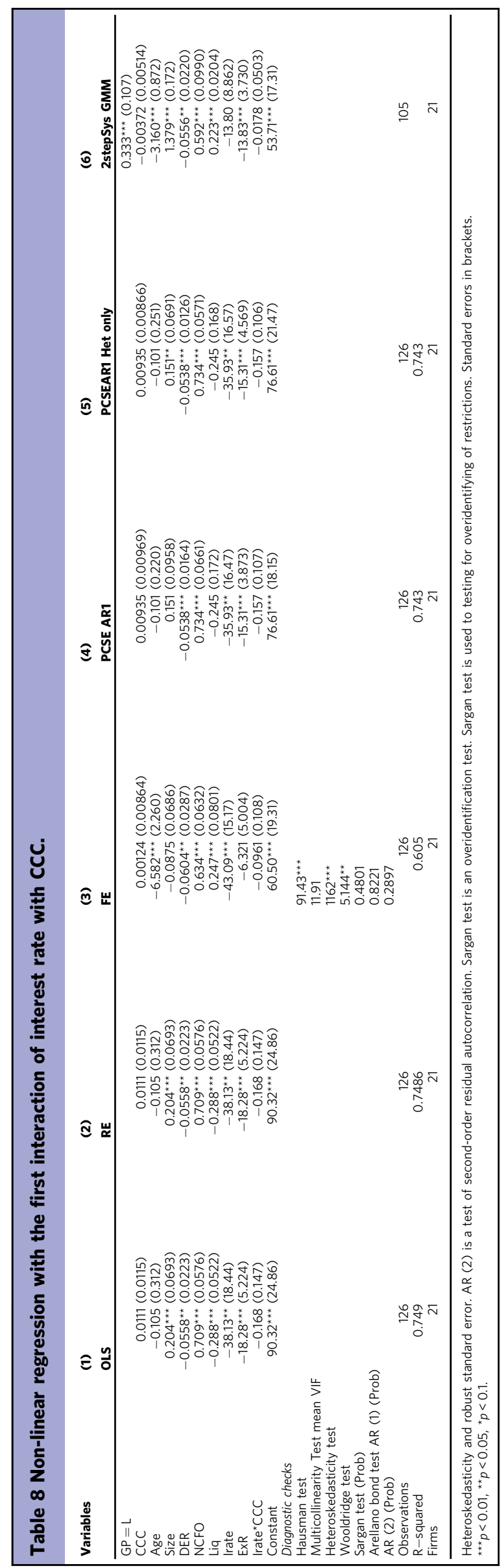



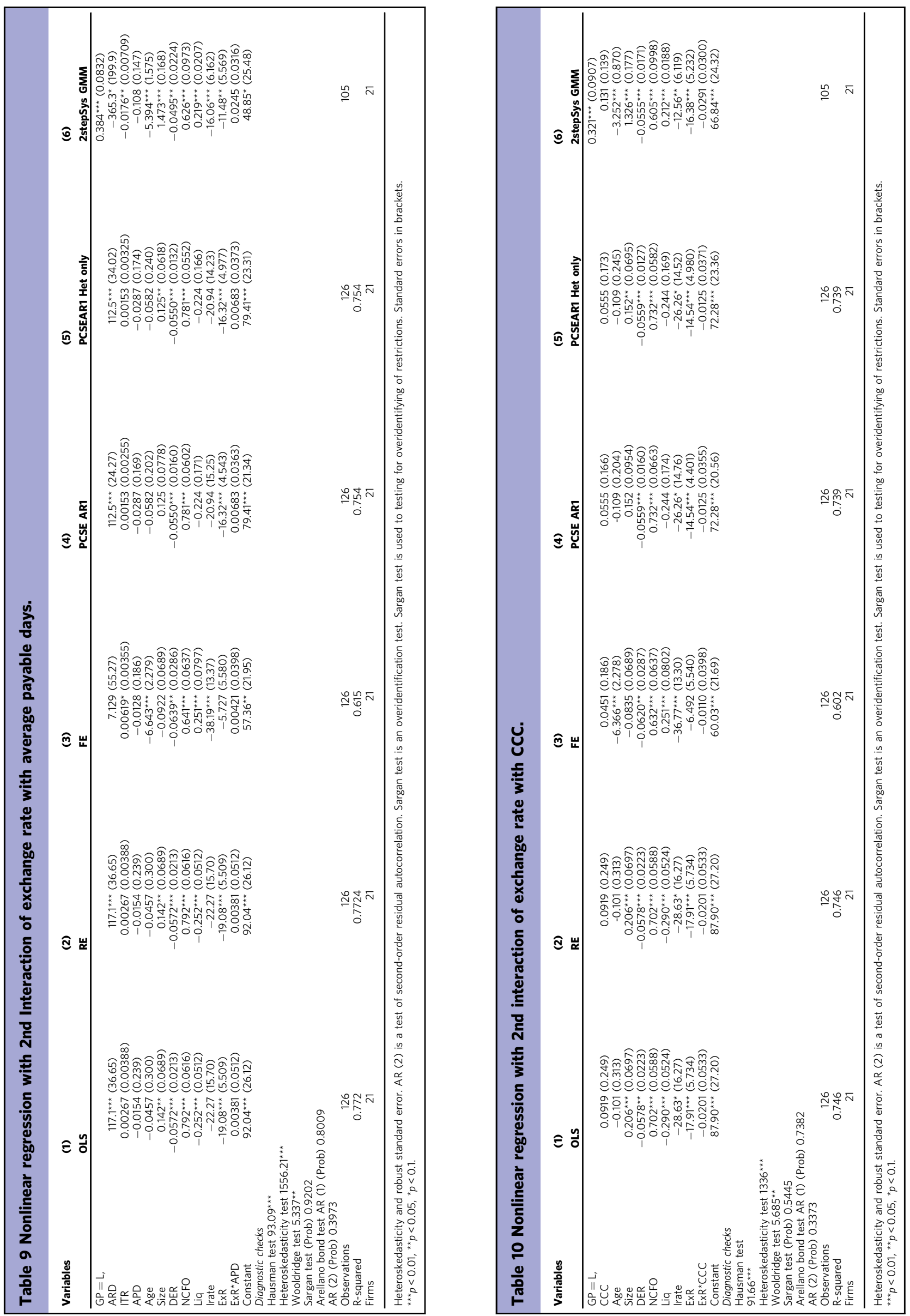
reverse if we include them in an observational model as an interaction variable. As the local currency is devalued and businesses extend the CCC duration, the exchange rate would positively affect and firm performance would be improved.

Limitations of the study. We want to make it clear that no study can be free of obstacles, as stated below:

- The research is limited to six years of data only, i.e., from 2013 to 2018. Accordingly, a complete investigation comprising an average time, which may provide somewhat mixed outcomes, could not produce significant inferences.

- This research is based on secondary data collected from the Officers of the State Bank. The investigation's nature depends only on the accuracy of the data and the secondary data's authenticity. The influence of the data source can affect the results of the estimation and explained the analysis results.

This research is based on 21 companies of the fuel and energy sector, extracted from corporations registered under KSE. Accordingly, the accuracy of the decisions is based on the data of the sample selected firms. The return can be somewhat contradictory if the potential researcher uses more time about the sample units.

\section{Data availability}

The data that support the findings of this study are available from the first, and corresponding author upon reasonable request.

Received: 16 November 2020; Accepted: 8 April 2021;

Published online: 18 May 2021

\section{References}

Adekola A, Samy M, Knight D (2017) Efficient working capital management as a tool for driving profitability and liquidity: correlation analysis of Nigerian companies. Int J Bus Global 18(2):251-275. https://doi.org/10.1504/IJBG.2017.081957

Ai C, Norton EC (2003) Interaction terms in logit and probit models. Econ Lett 80 (1):123-129. https://doi.org/10.1016/S0165-1765(03)00032-6

Ahmed F, Kousar S, Pervaiz A, Ramos-Requena JP (2020) Financial development, institutional quality, and environmental degradation nexus: new evidence from asymmetric ARDL co-integration approach. Sustainability 12(18):7812

Ahmed F, Kousar S, Pervaiz A, Ramos-Requena JP (2020) Financial development, institutional quality, and environmental degradation nexus: new evidence from asymmetric ARDL co-integration approach. Sustainability 12(18):7812

Alonso-Borrego C, Arellano M (1999) Symmetrically normalized instrumentalvariable estimation using panel data. J Bus Econ Stat 17(1):36-49. https://doi. org/10.1080/07350015.1999.10524795

Arellano M, Bond S (1991) Some tests of specification for panel data: Monte Carlo evidence and an application to employment equations Review of Economic Studies 58(2):277-297. https://doi.org/10.2307/2297968

Arellano M, Bover O (1995) Another look at the instrumental variable estimation of error-components models. Journal of Econometrics 68(1):29-51. https:// doi.org/10.1016/0304-4076(94)01642-D

Arena M, Azzone G, Piantoni G (2020) Shared value creation during site decommissioning: a case study from the energy sector. J Clean Prod 251:119587. https://doi.org/10.1016/j.jclepro.2019.119587

Asif M, Khan KB, Anser MK, Nassani AA, Abro MMQ, Zaman K (2020) Dynamic interaction between financial development and natural resources: evaluating the 'Resource curse' hypothesis. Resour Policy 65:101566

Aziz N, Sharif A, Raza A, Rong K (2020) Revisiting the role of forestry, agriculture, and renewable energy in testing environment Kuznets curve in Pakistan: evidence from Quantile ARDL approach. Environ Sci Pollut Res 1-14. https://doi.org/10.1007/s11356-020-07798-1

Bergeaud A, Raimbault J (2020) An empirical analysis of the spatial variability of fuel prices in the United States. Transp Res Part A 132:131-143. https://doi. org/10.1016/j.tra.2019.10.016

Beck N, Katz JN (2011) Modeling dynamics in time-series-cross-section political economy data Annual Review of Political Science 14:331-352. https://doi.org/ 10.1146/annurev-polisci-071510-103222
Blundell R, Bond S (1998) Initial conditions and moment restrictions in dynamic panel data models. J Econom 87(1):115-143. https://doi.org/10.1016/S03044076(98)00009-8

Bodislav DA, Bran F, Rădulescu CV (2020) Creating sustainable energy for future generations. In: Omran A., Schwarz-Herion O. (eds) Sustaining our environment for better future. Springer, Singapore. https://doi.org/10.1007/978981-13-7158-5 9

Boisjoly RP, Conine Jr TE, McDonald IV MB (2020) Working capital management: financial and valuation impacts. J Bus Res 108:1-8. https://doi.org/10.1016/j. jbusres.2019.09.025

Bowsher CG (2002) On testing overidentifying restrictions in dynamic panel data models. Econ Lett 77(2):211-220. https://doi.org/10.1016/S0165-1765(02) 00130-1

Bruyland E, Lasfer M, De Maeseneire W, Song W (2019) The performance of acquisitions by high default risk bidders. J Bank Financ 101:37-58. https:// doi.org/10.1016/j.jbankfin.2019.01.019

Chandra T, Sitompul SS, She JO (2016) Analysis of effect of proportion of independent commissioners, the audit committee, company size and debt to equity ratio of practice management profit on food and beverage company listed in Indonesia Stock Exchange. Soc Sci 11(13):3307-3314. https://doi.org/ $10.36478 /$ sscience. 2016.3307 .3314

Chernov D, Sornette D (2020) Specific features of risk management in the industrial and agricultural sectors. In: Critical risks of different economic sectors. Springer, Cham. https://doi.org/10.1007/978-3-030-25034-8_2

Chowdhury AY, Alam MZ, Sultana S, Hamid MK (2018) Impact of working capital management on profitability: a case study on pharmaceutical companies of Bangladesh. J Econ Bus Manag 6(1):27-35. https://doi.org/10.18178/ joebm.2018.6.1.546

Dalci I, Tanova C, Ozyapici H, Bein MA (2019) The moderating impact of firm size on the relationship between working capital management and profitability. Prague Econ Pap 28(3):296-312

Dao LKO, Nguyen TY, Hussain S, Nguyen VC (2020) Factors affecting nonperforming loans of commercial banks: the role of bank performance and credit growth. Banks Bank Syst 15(3):44-54. https://doi.org/10.21511/bbs.15 (3). 2020.05

Davis PE, Bendickson JS (2020) Strategic antecedents of innovation: variance between small and large firms. J Small Bus Manag 1-26. https://doi.org/ $10.1111 /$ jsbm. 12478

Gill A, Biger N, Mathur N (2010) The relationship between working capital management and profitability: Evidence from the United States. Bus Econ 10(1):1-9. https://doi.org/10.5539/ijbm.v12n8p175

Goel U, Sharma A (2015) Working capital management efficiency in Indian manufacturing sector: trends and determinants. Int J Econ Bus Res 10 (1):30-45. https://doi.org/10.1504/IJEBR.2015.070273

Gull AA, Arshad M (2013) Influence of working capital management and liquidity on financial soundness of firms listed at Karachi stock exchange IOSR J Bus Manag 11(2):52-57. https://doi.org/10.9790/487X-1125257

Hamza K, Mutala Z, Antwi SK (2015) Cash management practices and financial performance of small and medium enterprises (SMEs) in the northern region of Ghana. Int J Econ Commer Manag 3(7):456-480. https://doi.org/10.21276/sjbms

Hashemizedeh A, Bui Q, Kongbuamai N (2021) Unpacking the role of public debt in renewable energy consumption: new insights from the emerging countries. Energy 224:120187

Hussain S, Quddus A, Tien PP, Rafiq M, Pavelková D (2020) The moderating role of firm size and interest rate in capital structure of the firms: selected sample from sugar sector of Pakistan. Invest Manag Financ Innov 17(4):341-355. https://doi.org/10.21511/imfi.17(4).2020.29

Jadiyappa N, Vanga NR, Krishnankutty R (2016) Financial liberalisation and Capital structuringdecisions of corporate firms: Evidence from India. Econ Lett 149:33-37. https://doi.org/10.1016/j.econlet.2016.10.004

Karim R, Al-Mamun MA, Miah MT (2017) Relationship between working capital management efficiency and profitability: a comparative study on Square Pharmaceuticals Limited and Beximco Pharmaceuticals Limited, in Bangladesh. Int J Econ Financ Manag Sci 5(2):121-128. https://doi.org/10.11648/j. ijefm.20170502.16

Lazaridis I, Tryfonidis D (2006). Relationship between working capital management and profitability of listed companies in the Athens stock exchange. J Financ Manag Anal 19(1). https://doi.org/10.32479/ijeep.8406

Luc PT (2018) The relationship between perceived access to finance and social entrepreneurship intentions among university students in Vietnam. J Asian Financ Econ Bus 5(1):63-72

Majeed MT, Ozturk I (2020) Environmental degradation and population health outcomes: a global panel data analysis. Environ Sci Pollut Res 27:15901-15911. https://doi.org/10.1007/s11356-020-08167-8

Mate M, Occhino P (2020) A proposal to estimate the valuation of small and medium size companies using geographically comparable information. Small Bus Int Rev 4(1):34-51. https://doi.org/10.26784/sbir.v4i1.229 
Mazzarol T, Reboud S (2020) Cash flow, profit and working capital. In: Small business management. Springer Texts in Business and Economics. Springer, Singapore. https://doi.org/10.1007/978-981-13-9509-3_11

Moussa AA (2018) The impact of working capital management on firms' performance and value: evidence from Egypt. J Asset Manag 19(4):259-273. https:// doi.org/10.1057/s41260-018-0081-z

Nguyen TT, Nguyen VC, Tran TN (2020) Oil price shocks against stock return of oil and gas-related firms in the economic depression: a new evidence from a copula approach. Cogent Econ Financ 8(1):1799908. https://doi.org/10.1080/ 23322039.2020.1799908

Nguyen V (2020) Human capital, capital structure choice and firm profitability in developing countries: an empirical study in Vietnam. Accounting 6(2):127-136

Nuță AC, Nuță FM (2020) Modelling the influences of economic, demographic, and institutional factors on fiscal pressure using OLS, PCSE, and FD-GMM approaches. Sustainability 12(4):1681. https://doi.org/10.3390/su12041681

Nyblom J (1989) Testing for the constancy of parameters over time. J Am Stat Assoc 84(405):223-230. https://doi.org/10.1080/01621459.1989.10478759

Oseifuah E (2016) Determinants of working capital requirements: evidence from selected non-financial firms listed on the Johannesburg Securities Exchange. J Account Manag 6(1). https://doi.org/10.1080/23322039.2018.1558713

Öztürk H, Karabulut TA (2018) The relationship between earnings-to-price, current ratio, profit margin and return: an empirical analysis on Istanbul stock exchange. Account Financ Res 7(1):109-115. https://doi.org/10.5430/afr.v7n1p109

Peng J, Zhou Z (2019) Working capital optimization in a supply chain perspective. Eur J Oper Res 277(3):846-856. https://doi.org/10.1016/j.ejor.2019.03.022

Putri LP, Nasution AJP (2018) The effect of return on equity and sales growth to debt to equity ratio in corporate sector advertising, printing and media in Indonesia. https://doi.org/10.31219/osf.io/3qp4g

Restrepo F, Cardona-Sosa L, Strahan PE (2019) Funding liquidity without banks: evidence from a shock to the cost of very short-term debt. J Financ 74 (6):2875-2914. https://doi.org/10.2139/ssrn.2915349

Rosales A (2020) From norm entrepreneur to reluctant overachiever. Handbook of OPEC and the Global Energy Order: Past, Present and Future Challenges. Retreived from https://www.taylorfrancis.com/chapters/edit/10.4324/ 9780429203190-7/norm-entrepreneur-reluctant-overachiever-antuliorosales

Samiloglu F, Akgün Aİ (2016) The relationship between working capital management and profitability: evidence from Turkey. Bus Econ Res J 7(2):1. https://doi.org/10.20409/berj.2016217492

Seth H, Chadha S, Ruparel N, Arora PK, Sharma SK (2020) Assessing working capital management efficiency of Indian manufacturing exporters. Manag Financ 46(8):1061-1079

Simon S, Sawandi N, Ali Abdul-Hamid M (2019) Working capital management and firm performance: the moderating effect of inflation rates. Pertanika J Soc Sci Humanit 27:1

Song H, Yang X, Yu K (2020) How do supply chain network and SMEs' operational capabilities enhance working capital financing? An integrative signaling view. Int J Prod Econ 220:107447. https://doi.org/10.1016/j.ijpe.2019.07.020

Sunday S (2018) The moderating effect of economic conditions on the relationship between working capital management and firm performance in Nigeria. Doctoral dissertation, Universiti Utara Malaysia

Tan LP, Pham LX, Bui TT. Personality traits and social entrepreneurial intention: the mediating effect of perceived desirability and perceived feasibility. J Entrep 30(1), 56-80

Tan LP, Le ANH, Xuan LP (2019) A systematic literature review on social entrepreneurial intention. J Soc Entrep 11(3):241-256

Tran TN, Nguyen TT, Nguyen VC, Vu TTH (2020) Energy consumption, economic growth and trade balance in East Asian-a panel data approach. Int J Energy Econ Policy 10(4):443-449. https://doi.org/10.32479/ijeep.9401

Tsagem MM (2020) Cash conversion cycle and profitability of Nigerian small and medium-sized entities: an empirical analysis. Int J Ban Financ 13(1):49-69. https://doi.org/10.11648/j.jfa.20160406.15

Ukaegbu B (2014) The significance of working capital management in determining firm profitability: Evidence from developing economies in Africa. Res Int Bus Financ 31:1-16. https://doi.org/10.1016/j.ribaf.2013.11.005

Umadevi S, Boopathiraj T (2020) A study on liquidity position of Ashok Leyland Limited. Our Heritage 68(30):5916-5922. https://doi.org/10.36106/ijar
Veenstra G, Vanzella-Yang A (2020). Family income and self-rated health in Canada: Using fixed effects models to control for unobserved confounders and investigate causal temporality. Soc Sci Med 112884. 10.1016/j

Wang Z, Akbar M, Akbar A (2020) The Interplay between working capital management and a firm's financial performance across the corporate life cycle. Sustainability 12(4):1661. https://doi.org/10.3390/su12041661

Wang Z, Bui QV, Zhang B, Nawarathna, Chulan LKN, Claudel M (2021) The nexus between renewable energy consumption and human development in BRICS countries: the moderating role of public debt. Renew Energy 165 (1):381-390

Wattoo WA, Kaloi GS, Yousif M, Baloch MH, Zardari BA, Arshad J, Tahir S (2020) An optimal asset allocation strategy for suppliers paying carbon tax in the competitive electricity market. J Electr Eng Technol 15(1):193-203. https:// doi.org/10.1007/s42835-019-00318-3

Wichitsathian S (2019) Working capital management and its impacts on profitability: the case of small and medium food enterprises in Nakhon Ratchasima, Thailand. Int J Econ Policy Emerg Econ 12(2):113-120. https://doi. org/10.1504/IJEPEE.2019.099733

Windmeijer F (2005) A finite sample correction for the variance of linear efficient two-step GMM estimators. J Econom 126(1):25-51. https://doi.org/10.1016/j. jeconom.2004.02.005

Zaher H, Illescas GM (2020) The Moderating Effect Of Firms'cash Holding On The Relation Between Cash Conversion Cycle And Firm Performance. Economic and Social Development: Book of Proceedings, 307-316. Varazdin: Varazdin Development and Entrepreneurship Agency(VADEA). Retrieved from https:// search.proquest.com/openview/8a88aele83e013d2baf8bf56celb52ac/1.pdf?cbl= 2033472\&pq-origsite $=$ gscholar

\section{Acknowledgements}

We thank all team members (Sarfraz Hussain - mianfraz1@gmail.com, Van Chien Nguyen - chienmpp3@gmail.com, Quang Minh Nguyen - nguyenquangminhhpu@gmail.com, Huu Tinh Nguyen - tinhnh@tdmu.edu.vn, Thu Thuy Nguyen - nguyenthuthuy@tmu.edu.vn).

\section{Competing interests}

The authors declare no competing interests.

\section{Additional information}

Correspondence and requests for materials should be addressed to V.C.N.

Reprints and permission information is available at http://www.nature.com/reprints

Publisher's Note Springer Nature remains neutral with regard to jurisdictional claims in published maps and institutional affiliations.

Open Access This article is licensed under a Creative Commons Attribution 4.0 International License, which permits use, sharing, adaptation, distribution and reproduction in any medium or format, as long as you give appropriate credit to the original author(s) and the source, provide a link to the Creative Commons license, and indicate if changes were made. The images or other third party material in this article are included in the article's Creative Commons license, unless indicated otherwise in a credit line to the material. If material is not included in the article's Creative Commons license and your intended use is not permitted by statutory regulation or exceeds the permitted use, you will need to obtain permission directly from the copyright holder. To view a copy of this license, visit http://creativecommons.org/ licenses/by/4.0/

(C) The Author(s) 2021 